\title{
Perioperative Therapy for Non-Small Cell Lung Cancer with Immune Checkpoint Inhibitors
}

\author{
Junichi Soh *(D), Akira Hamada (D), Toshio Fujino and Tetsuya Mitsudomi
}

check for updates

Citation: Soh, J.; Hamada, A.; Fujino, T.; Mitsudomi, T. Perioperative Therapy for Non-Small Cell Lung Cancer with Immune Checkpoint Inhibitors. Cancers 2021, 13, 4035. https://doi.org/10.3390/cancers 13164035

Academic Editor: Charles B. Simone

Received: 15 July 2021

Accepted: 4 August 2021

Published: 10 August 2021

Publisher's Note: MDPI stays neutral with regard to jurisdictional claims in published maps and institutional affiliations.

Copyright: (c) 2021 by the authors. Licensee MDPI, Basel, Switzerland. This article is an open access article distributed under the terms and conditions of the Creative Commons Attribution (CC BY) license (https:/ / creativecommons.org/licenses/by/ $4.0 /)$.
Division of Thoracic Surgery, Department of Surgery, Kindai University Faculty of Medicine, 377-2 Ohno-higashi, Osaka-Sayama, Osaka 589-8511, Japan; a-hamada@med.kindai.ac.jp (A.H.); t-fujino@surg.med.kindai.ac.jp (T.F.); mitsudom@med.kindai.ac.jp (T.M.)

* Correspondence: soh.j@med.kindai.ac.jp; Tel.: +81-72-366-0221

Simple Summary: This review presents the development of perioperative treatment using immune checkpoint inhibitors (ICIs) in patients with resectable non-small cell lung cancers. There are several ongoing phase 3 trials for adjuvant and neoadjuvant ICI therapies. The results of the adjuvant (IMpower010 trial) and the neoadjuvant (Checkmate 816 trial) ICI phase 3 trials have shown prolonged disease-free survival and increased pathological complete response rate, respectively. Based on the hypothesis that 'preoperative ICI treatment, especially in combination with conventional chemotherapy, promotes a higher immune response because of preservation of the immune environment', neoadjuvant trials using ICIs and conventional chemotherapy in combination are currently being conducted more frequently than adjuvant ICI trials. Multimodality approaches using chemoradiotherapy and new ICI agents are also being examined in several phase 2 trials. To maximise ICI therapy's efficacy and to minimise futile administration, methodologies for predicting and monitoring the therapeutic effects, such as detecting minimal residual disease, need to be established.

Abstract: The emergence of immune checkpoint inhibitors (ICIs) has dramatically changed the treatment landscape for patients with metastatic non-small cell lung cancer (NSCLC). These achievements inspired investigators and pharmaceutical companies to conduct clinical trials in patients with early-stage NSCLC because both adjuvant and neoadjuvant platinum-based doublet chemotherapies (PT-DCs) showed only a 5\% improvement in 5-year overall survival. IMpower010, a phase 3 trial (P3), showed that adjuvant PT-DC followed by maintenance atezolitumab significantly prolonged diseasefree survival over adjuvant PT-DC alone (hazard ratio, 0.79; stage II to IIIA). Since conventional therapies, including chemotherapy and radiotherapy, can promote immunogenic cell death, releasing tumour antigens from dead tumour cells, ICI combination therapies with conventional therapies are widely proposed. The Checkmate 816 trial (P3) indicated a significantly higher pathological complete response rate of neoadjuvant nivolumab/PT-DC combination therapy than of neoadjuvant PT-DC alone (odds ratio, 13.9, for stage IB to IIIA). Detection of circulating tumour DNA is highly anticipated for the evaluation of minimal residual disease. Multimodal approaches and new ICI agents are being attempted to improve the efficacy of ICI treatment in phase 2 trials. This review presents the development of perioperative treatment using ICIs in patients with NSCLC while discussing problems and perspectives.

Keywords: lung cancer; immune checkpoint inhibitor; perioperative therapy; neoadjuvant therapy; adjuvant therapy

\section{Introduction}

Lung cancer remains the leading cause of cancer-related mortality worldwide [1]. Only a small fraction of patients can be treated with curative intent. Although surgery offers the best chance for a cure, the 5-year overall survival (OS) rates of patients who have to undergo pulmonary resection are unsatisfactory, with rates of $68 \%, 60 \%, 53 \%$, and $36 \%$ for pathological stages IB/IIA/IIB/IIIA, respectively [2]. 
Cancer recurrence risk reduction, especially for distant recurrence, is essential for patients to achieve long-term survival after surgery. Distant recurrence occurs due to the progression of minimal residual disease (MRD), which is considered to be metastasised cancer cells that are undetectable in imaging studies prior to surgery. The current standard treatment modality for patients with pathological stage II to III non-small cell lung cancer (NSCLC) is adjuvant therapy using platinum-based doublet chemotherapy (PT-DC). However, the lung adjuvant cisplatin evaluation (LACE) meta-analysis of five randomised phase 3 trials reported that adjuvant PT-DC could improve 5-year survival by only 5.4\% in patients after complete resection of NSCLC [3].

The advent of immune checkpoint inhibitors (ICIs) targeting programmed cell death 1 (PD-1), programmed death ligand 1 (PD-L1), and cytotoxic T-lymphocyte-associated protein 4 (CTLA4) has led to a durable response and improved prognosis in patients with metastatic lung cancer [4-6]. In addition, the PACIFIC trial reported that concurrent chemoradiation followed by maintenance therapy with durvalumab, a PD-L1 antibody, prolonged progression-free survival (PFS) and OS. Hence, this regimen has become the standard of care for patients with unresectable stage III NSCLC [7,8]. Thus, the application of ICIs to patients with early-stage lung cancer has been actively pursued. This article summarises perioperative treatments using ICIs in patients with NSCLC and discusses future perspectives.

\section{Current Status of Perioperative Therapy}

The evidence for adjuvant chemotherapy using cytotoxic agents has been well established. In 2008, the LACE meta-analysis of five phase 3 trials [3] showed that adjuvant chemotherapy using PT-DC significantly improved OS in completely resected patients with NSCLC (hazard ratio (HR) $=0.89,95 \%$ confidence interval $(\mathrm{CI}): 0.82-0.96, p=0.005$ ). Furthermore, a subset analysis showed that adjuvant therapy using PT-DC improved OS in stage II (HR = 0.83; 95\% CI: 0.73-0.95) and stage III (HR = 0.83, 95\% CI: 0.72-0.94), but it was determined to be harmful in stage I NSCLC.

The evidence for the neoadjuvant chemotherapy results, although insufficient compared to that for adjuvant therapy, through a review and meta-analysis conducted by the NSCLC Meta-analysis Collaborate Group, showed that neoadjuvant chemotherapy followed by surgery for stage I to III NSCLC improved the 5-year OS by 5\% (40-45\%) $(\mathrm{HR}=0.87,95 \% \mathrm{CI}: 0.78-0.96, p=0.007)$ compared to surgery alone [9].

Limited evidence is available regarding the efficacy of the induction CRT followed by surgery. However, the INT0139 study, a phase 3 trial, compared the standard of care radical chemoradiotherapy (CRT) with induction CRT (45 Gy) followed by surgery for pathologically proven cN2 resectable NSCLC [10]. The trial reported that in an exploratory subset analysis, pneumonectomy after CRT induction was associated with a $26 \%$ treatmentrelated mortality rate and a worse OS than radical CRT. In contrast, lobectomy after CRT induction was associated with a $1 \%$ treatment-related mortality rate and significantly better OS than radical CRT (median OS, 33.6 vs. 21.7\%, $p=0.002$ ).

\section{Initiation of Clinical Trials for Perioperative Therapy by ICI}

ICIs improve the prognosis of patients with metastatic NSCLC [4-6,11-13]. These achievements have encouraged the introduction of immunotherapy as an adjuvant, neoadjuvant, or both for patients with earlier-stage lung cancer.

Several large-scale phase 3 studies are underway in an adjuvant setting, investigating the efficacy of ICIs after complete resection in patients with pathological stage IB to IIIA NSCLC (Table 1). There are currently at least seven phase 3 studies, including five ICI monotherapies and two combination therapies for ICI and conventional chemotherapy, estimated to accrue 5347 patients, in progress. 
Table 1. Phase 3 clinical trials of adjuvant therapy using ICIs.

\begin{tabular}{|c|c|c|c|c|c|c|c|c|c|}
\hline Registration \# & Trial & Therapy & $\mathbf{N}$ & Pretreatment & $\begin{array}{c}\text { Experimental } \\
\text { Arm }\end{array}$ & Control Arm & $\begin{array}{l}\text { Primary } \\
\text { Endpoint }\end{array}$ & Stage & Country \\
\hline NCT02273375 & BR.31 & $\begin{array}{l}\text { ICI } \\
\text { mono }\end{array}$ & 1360 & $\begin{array}{l}\text { Yes/No } \\
\text { PT-DC }\end{array}$ & $\begin{array}{c}\text { durvalumab } \\
1 \text { year }\end{array}$ & Placebo & DFS & pIB to IIIA & Global \\
\hline NCT02486718 & IMpower010 & $\begin{array}{l}\text { ICI } \\
\text { mono }\end{array}$ & 1280 & $\begin{array}{l}\text { Yes/No } \\
\text { PT-DC }\end{array}$ & $\begin{array}{l}\text { Atezolizumab } \\
1 \text { year }\end{array}$ & BSC & DFS & pIB to IIIA & Global \\
\hline NCT02504372 & $\begin{array}{c}\text { PEARLS/KEYNOTE- } \\
091\end{array}$ & $\begin{array}{l}\text { ICI } \\
\text { mono }\end{array}$ & 1177 & $\begin{array}{l}\text { Yes/No } \\
\text { PT-DC t }\end{array}$ & $\begin{array}{c}\text { pembrolizumab } \\
1 \text { year }\end{array}$ & Placebo & DFS & pIB to IIIA & Global \\
\hline NCT02595944 & ANVIL & $\begin{array}{c}\text { ICI } \\
\text { mono }\end{array}$ & 714 & $\begin{array}{l}\text { Yes/No } \\
\text { PT-DC }\end{array}$ & $\begin{array}{l}\text { nivolumab } \\
1 \text { year }\end{array}$ & Observation & DFS/OS & pIB to IIIA & US \\
\hline NCT04642469 & MeRmaiD-2 & $\begin{array}{l}\text { ICI } \\
\text { mono }\end{array}$ & 284 & $\begin{array}{l}\text { Yes/No } \\
\text { PT-DC }\end{array}$ & durvalumab & Placebo & $\begin{array}{c}\text { DFS in } \\
\text { PD-L1 } \\
\text { TC } \geq 1 \%\end{array}$ & $\begin{array}{c}\text { II to III } \\
\text { without } \\
\text { positive } \\
\text { EGFR/ALK }\end{array}$ & Global \\
\hline NCT04385368 & MeRmaiD-1 & $\begin{array}{l}\text { ICI } \\
\text { chemo }\end{array}$ & 322 & No & $\begin{array}{l}\text { durvalumab + } \\
\text { standard of care } \\
\text { chemotherapy }\end{array}$ & $\begin{array}{c}\text { Placebo + } \\
\text { standard of care } \\
\text { chemotherapy }\end{array}$ & DFS & $\begin{array}{c}\text { II to III } \\
\text { without } \\
\text { positive } \\
\text { EGFR/ALK }\end{array}$ & Global \\
\hline NCT04564157 & $\begin{array}{l}\text { NADIM- } \\
\text { ADJUVANT }\end{array}$ & $\begin{array}{l}\text { ICI } \\
\text { chemo }\end{array}$ & 210 & No & $\begin{array}{c}\text { Nivolumab + } \\
\text { CBDCA/PTX } \\
\text { (4 times) } \\
\text { Maintenance: } \\
\text { nivolumab } \\
\text { (6 times) }\end{array}$ & $\begin{array}{c}\text { Nivolumab + } \\
\text { CBDCA/PTX } \\
\text { (4 times) } \\
\text { Maintenance: } \\
\text { Observation }\end{array}$ & DFS & $\begin{array}{l}\text { pIB }(\geq 4 \mathrm{~cm}) \\
\text { to IIIA }\end{array}$ & Spain \\
\hline
\end{tabular}

\#, number; ICI, immune checkpoint inhibitor; PT-DC, platinum-based doublet chemotherapy; Sq, squamous cell carcinoma, CDDP, cisplatin; CBDCA, carboplatin; PTX, paclitaxel; BSC, best supportive care; DFS, disease-free survival; OS, overall survival; TC, tumor cells.

Recently, the main findings of the IMpower010 trial revealed that adjuvant chemotherapy followed by maintenance with atezolizumab showed the significant prolongation of disease-free survival (DFS) in patients with PD-L1 TC $\geq 1 \%$ (per SP 263) stage II to IIIA (HR, 0.66; 95\% CI, 0.50-0.88) NSCLC [14]. Hierarchical analysis showed a significant prolongation of DFS in patients with all-randomised stage II to IIIA (HR, 0.79; 95\% CI, $0.64-0.96)$ and in the intention-to-treat population with stage IB to IIIA (HR, 0.81; 95\% CI, 0.67-0.99). The 3-year DFS rate was 55.7\% in patients with all-randomised stage II to IIIA who received maintenance atezolizumab compared to the $49.4 \%$ in those who did not receive maintenance atezolizumab $(p=0.02)$. Among patients with all-randomised stage II to IIIA, under atezolizumab administration, patients with high PD-L1 expression of TC $\geq 50 \%$ (HR $0.43 ; 95 \%$ CI, $0.27-0.68$ ) received the greatest benefit in terms of DFS. No survival benefit was observed in patients with the PD-L1 expression of TC $<1 \%$ (HR, 0.97; $95 \%$ CI, 0.72-1.31) after maintenance atezolizumab administration.

\section{Neoadjuvant vs. Adjuvant}

There is a possibility that neoadjuvant therapy may control micrometastases in the early phases and may offer an opportunity to evaluate drug sensitivity. Thus, it could be used as a guide in determining the postoperative regimen (Figure 1). Adjuvant therapy may or may not be performed under a reduced drug regimen if the patients' performance status worsens after surgery. Neoadjuvant therapy can be performed with good compliance. However, neoadjuvant therapy may cause increased postoperative complications and treatment-related adverse events (TRAE), leading to delays in surgery or inoperability $[15,16]$.

T cells are activated by the recognition of the presented tumour antigen. They travel through the lymphatic stream and the bloodstream to the primary and metastatic sites and exert anti-tumour effects. Hence, it has been argued that neoadjuvant ICI therapy may be more effective than adjuvant ICI therapy because lymphatic and blood flow between the tumour and regional lymph nodes are maintained in neoadjuvant therapy but not in adjuvant therapy [17]. These hypotheses were experimentally examined by comparing neoadjuvant and adjuvant ICI therapies using a mouse subcutaneous tumour transplantation model [18]. Mice treated with neoadjuvant ICI therapy had longer survival than those treated with adjuvant ICI therapy did. 


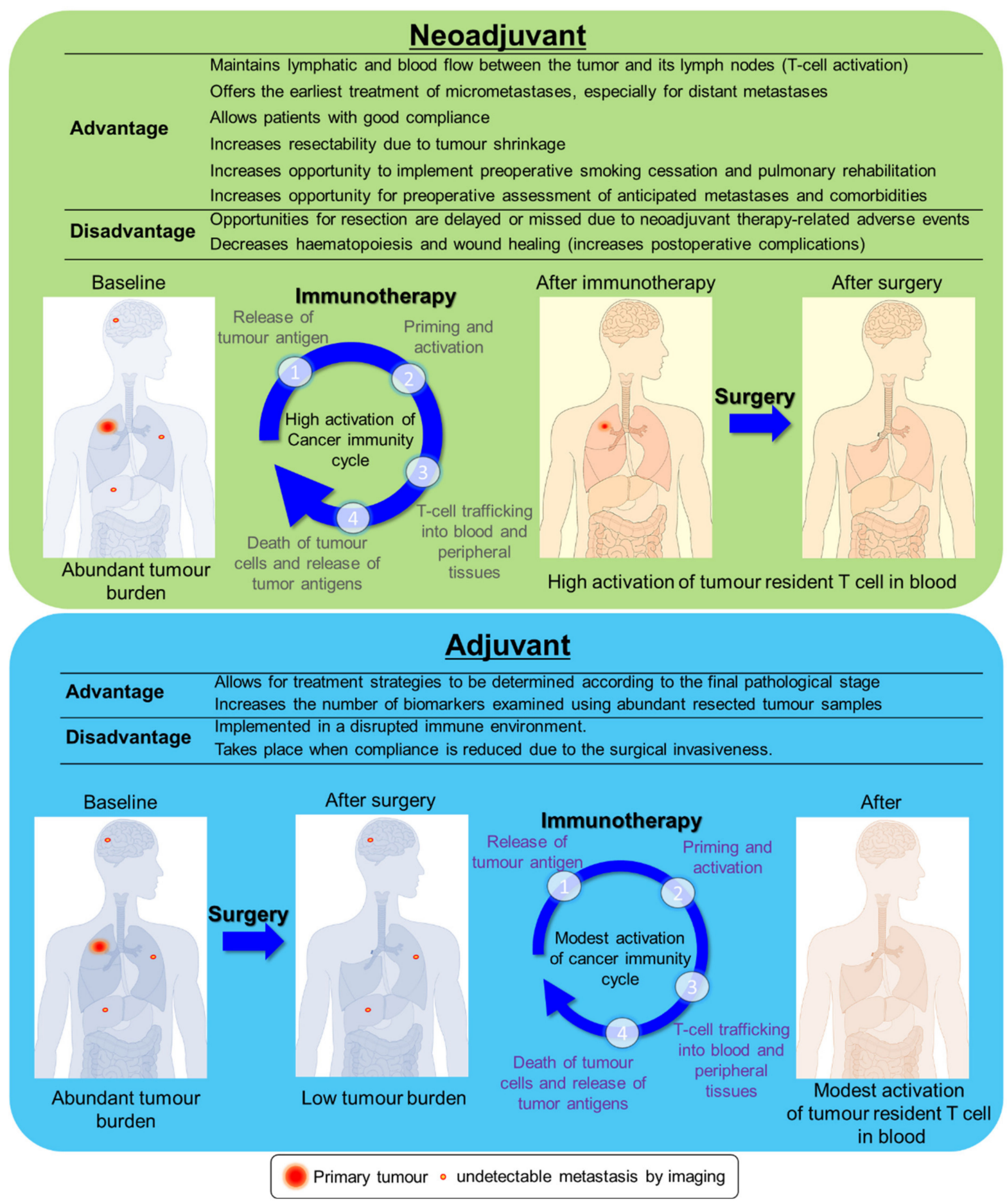

Figure 1. Comparison of neoadjuvant and adjuvant immunotherapies. Neoadjuvant immunotherapy is performed under an abundant tumour burden, which may promote high activation of cancer immunity (upper panel). In contrast, adjuvant immunotherapy is performed under a low tumour burden, but immunotherapy may induce enough efficacy to only control residual disease (lower panel). 
In clinical trials for neoadjuvant and adjuvant therapies, the gold standard for the primary endpoint is OS. Since it takes a long time to obtain the final OS results, it would be challenging to provide a promising novel agent for clinical practice within a short time frame. Several clinical trials for patients with breast cancer [19-22] have used the degree of pathologic response, such as major pathologic response (MPR) and pathological complete response ( $\mathrm{pCR}$ ), as primary endpoints. Regarding lung cancers, retrospective studies have shown that significant prognostic improvement is observed in patients who showed MPR after neoadjuvant cytotoxic chemotherapy, where MPR is defined as $\leq 10 \%$ of the viable residual tumour [23,24]. Although various methods of assessing MPR have been used, they have not been defined in detail [23-26]. For example, different MPR cut-off values were proposed based on the histological subtypes [27]. In 2020, the International Association for the Study of Lung Cancer published a recommendation for the pathologic assessment of resected specimens after neoadjuvant therapy [28]: a standardised approach is recommended to assess the percentages of (1) viable tumour, (2) necrosis, and (3) stroma (including inflammation and fibrosis) with a total adding up to $100 \%$, and the definition of MPR is $\leq 10 \%$ of viable tumour in the primary tumour bed. Since the pathologic response of resected specimens can be assessed only after the completion of surgery, it is essential to establish predictive markers before therapeutic administration in the selection of patients who are expected to benefit and not be harmed from perioperative treatment.

\section{Clinical Trials of Neoadjuvant Mono- or Dual ICI Therapy}

Various clinical trials of neoadjuvant ICI monotherapy or dual ICI therapy are being conducted. Among these trials, the results of five trials have been reported: four ICI monotherapy trials and one dual ICI therapy trial (Table 2). The proportion of patients who could not undergo surgery ranged from 0 to $12 \%$ in the four ICI monotherapy trials but was $19 \%$ in the dual ICI therapy trial. Complete resection (R0 resection) was achieved in more than $90 \%$ of the patients. The MPR rate ranged from $21 \%$ to $45 \%$ in all trials in which more than two doses of ICI were scheduled. However, none of the patients showed an MPR in the PRINCEPS trial, in which only one dose of atezolizumab was administered [29].

The NEOSTAR trial is a randomised phase 2 trial of nivolumab monotherapy (the nivolumab arm) or nivolumab plus ipilimumab (the nivolumab plus ipilimumab arm) followed by surgery in patients with clinical stage I to IIIA NSCLCs [30]. The incidence of TRAEs of $\geq$ G3 was equivalent between the two arms (13\% in the nivolumab arm vs. $10 \%$ in the nivolumab plus ipilimumab arm). However, MPR and pCR were more prevalent in the nivolumab plus ipilimumab arm than in the nivolumab arm: $38 \%$ vs. $22 \%$ and $29 \%$ vs. $9 \%$, respectively (not statistically significant). 
Table 2. Results of clinical trials using neoadjuvant ICI-mono or -dual therapy.

\begin{tabular}{|c|c|c|c|c|c|c|c|c|c|c|c|c|c|}
\hline Registration \# & Trial \& Stage & $\begin{array}{l}\text { Neoadjuvant } \\
\text { Therapy }\end{array}$ & N (Plan) & $\begin{array}{c}\mathrm{N} \\
\text { (Reported) }\end{array}$ & $\begin{array}{c}\text { Delay of } \\
\text { Surgery }(\%)\end{array}$ & $\begin{array}{l}\text { Failure to } \\
\text { Surgery (\%) }\end{array}$ & $\begin{array}{c}\text { R0 } \\
\text { Resection } \\
(\%)\end{array}$ & $\begin{array}{c}\text { TRAE } \\
(\geq \text { G3) (\%) }\end{array}$ & MPR (\%) & pCR (\%) & Survival & Status & Ref. \\
\hline NCT02259621 & $\begin{array}{l}\text { Johns Hopkins } \\
\text { Univ. (p2) } \\
\text { IB }(>4 \mathrm{~cm}) \text { to IIIA }\end{array}$ & $\begin{array}{l}\text { nivolumab } \\
\text { (twice) }\end{array}$ & 30 & 22 & 0 & 0 & 95 & Preope: 4.5 & 45 & 15 & $\begin{array}{c}\text { Median } \\
\text { RFS: NR } 18 \\
\text { m } \\
\text { RFS: } 73 \%\end{array}$ & $\begin{array}{l}\text { On } \\
\text { going }\end{array}$ & [31] \\
\hline NCT02927301 & $\begin{array}{c}\text { LCMC3 (p2) } \\
\text { IB to IIIA, IIIB } \\
\text { (T3N2, T4 (size)) }\end{array}$ & $\begin{array}{l}\text { atezolizumab } \\
\quad \text { (twice) }\end{array}$ & 180 & 181 & 12 & 12 & 92 & $\begin{array}{l}\text { Preope: } 6 \\
\text { Postope: } 14\end{array}$ & 21 & 7 & $\begin{array}{c}1 \text { y DFS: } \\
85 \% \\
1 \text { y OS: } 95 \%\end{array}$ & $\begin{array}{l}\text { On } \\
\text { going }\end{array}$ & [32] \\
\hline NCT03030131 & $\begin{array}{l}\text { IONESCO (p2) } \\
\text { IB to IIIA }\end{array}$ & $\begin{array}{l}\text { durvalumab } \\
\text { (3 times) }\end{array}$ & 81 & 46 & No data & 0 & 90 & $\begin{array}{c}\text { ICI-related: } \\
0 \\
\text { (Death:9) }\end{array}$ & No data & $\begin{array}{l}\text { No } \\
\text { data }\end{array}$ & $\begin{array}{c}\text { Median } \\
\text { OS/DFS: } \\
\text { NR/NR } 18 \\
\text { m OS/DFS: } \\
89 \% / 70 \%\end{array}$ & $\begin{array}{l}\text { Terminated } \\
\left(\text { mortality }{ }^{*}\right)\end{array}$ & [33] \\
\hline NCT03158129 & $\begin{array}{l}\text { NEOSTAR (p2) } \\
\text { I to IIIA }\end{array}$ & $\begin{array}{c}\text { nivolumab } \\
\text { (3 times) } \\
\text { or } \\
\text { nivolumab } \\
\text { (3 times) } \\
+ \\
\text { ipilimumab }\end{array}$ & 44 & 44 & 22 & $\begin{array}{c}\text { Nivo: } 4 \\
\text { N + I: } 19\end{array}$ & 100 & $\begin{array}{l}\text { Nivo: } 13 \\
\text { N + I: } 10\end{array}$ & $\begin{array}{l}\text { Nivo: } 22 \\
\text { N + I: } 38\end{array}$ & $\begin{array}{c}\text { Nivo: } 9 \\
\text { N + I: } 29\end{array}$ & $\begin{array}{l}\text { Median } \\
\text { OS/RFS: } \\
\text { NR/NR }\end{array}$ & $\begin{array}{l}\text { On } \\
\text { going }\end{array}$ & [30] \\
\hline
\end{tabular}

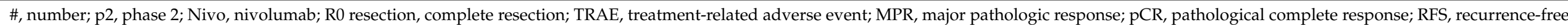
survival; OS, overall survival; DFS, disease-free survival; NR, not reached; $N+I$, nivolumab + ipilimumab; ${ }^{*}$, an excess in 90 -day postoperative mortality ( 4 deaths, $9 \%$ ). 


\section{Clinical Trials for ICI Combination Therapy with Chemotherapy or Chemoradiotherapy}

Tumours lacking an immune response are known as 'cold tumours'. Conventional therapies, such as chemotherapy and radiation therapy, are known to turn 'cold tumours' into 'hot tumours' with immune responses elicited by the tumour antigens released from cancer cell deaths (i.e., immunogenic cell death), thus increasing the therapeutic effects of ICI [34].

Various neoadjuvant ICI combination therapies have been widely proposed (Table S1). Phase 3 trials are underway that are exploring combination therapies with ICI against conventional chemotherapy (Table S1): Checkmate 816 (NCT02998528: nivolumab plus PT-DC), KEYNOTE-671 (NCT03425643: pembrolizumab plus PT-DC with adjuvant pembrolizumab), IMpower030 (NCT03456063: atezolizumab plus PT-DC), AEGEAN (NCT03800134: durvalumab plus PT-DC), and Checkmate 77T (NCT04025879: nivolumab plus PT-DC). Among them, the recent results of the phase 3 trial of Checkmate 816 showed that the proportions of failure to undergo surgery, R0 resection, and TRAE of $\geq \mathrm{G} 3$ were equivalent between the combination therapy of nivolumab plus PT-DC and PT-DC alone ( $16 \%$ vs. $21 \%, 83 \%$ vs. $78 \%$, and $19 \%$ and $21 \%$, respectively). Nevertheless, the MPR and $\mathrm{pCR}$ rates were significantly higher in the combination therapy with nivolumab plus PT-DC than in the PT-DC therapy alone: $36.9 \%$ vs. $8.9 \%(p<0.0001)$ and $24 \%$ vs. $2.2 \%$ $(p<0.0001)$, respectively [35] (Table 3). Survival data of this phase 3 trial are not currently available.

A phase 2 NCT03480230 trial exploring the combination therapy of PT-DC with avelumab was terminated because of the low response rate (Table 3). In the other phase 2 trials, the proportion of patients who could not successfully undergo surgery ranged from $3 \%$ to $27 \%$, and R0 resection was achieved in $87-100 \%$ of the patients. An MPR could be achieved in $57-83 \%$ of the patients, and a TRAE of $\geq \mathrm{G} 3$ was observed in $>27 \%$ of patients. The results of the NADIM trial exploring the neoadjuvant combination therapy of carboplatin/paclitaxel plus nivolumab before surgical resection followed by adjuvant nivolumab showed favourable PFS rates of $95.7 \%$ and $77.1 \%$ at 1 and 2 years, respectively [36].

The 'abscopal effect', which is the effect of ionising radiation 'at a distance from the irradiated volume but within the same organism', was first reported in 1953 [37]. This phenomenon was revealed to be immune-mediated [38] and has been observed in combination therapy trials when ICIs are administered sequentially or concurrently with radiotherapy [39]. The PACIFIC trial examined the benefits of durvalumab maintenance therapy after concurrent CRT [8]. The results showed that durvalumab maintenance therapy significantly prolonged both PFS (median PFS, 17.2 vs. 5.6 months, $\mathrm{HR}=0.51$, with 95\% CI: 0.41-0.63) [7] and OS (median OS, not reached vs. 29.1 months, $\mathrm{HR}=0.69,95 \%$ CI: 0.55-0.86) [40], indicating the usefulness of sequential ICI therapy after CRT.

Several multimodal approaches, in which radiotherapy is added to a combination therapy of ICI and conventional chemotherapy, have been used to improve treatment effects (Table S1) further. Interim analysis of a phase 2 trial exploring a multimodality therapy using durvalumab, PT-DC, and radiotherapy (45 Gy) (NCT03694236) indicated high MPR and $\mathrm{pCR}$ rates of $72.7 \%$ and $36.4 \%$, respectively, along with a relatively low rate of TRAEs of $\geq$ G3 (7\%) [41] (Table 3). We are also conducting a multicentre, prospective, single-arm, phase 2 trial of neoadjuvant concurrent chemo-immuno-radiation therapy (carboplatin plus paclitaxel and durvalumab with $50 \mathrm{~Gy}$ radiation therapy) followed by surgical resection and adjuvant immunotherapy for resectable stage IIIA-B (discrete N2) NSCLC (WJOG12119L: SQUAT trial) (Japic-CTI-195069) [42] (Table S1). 
Table 3. Results of clinical trials of neoadjuvant therapy of combination regimens of ICIs.

\begin{tabular}{|c|c|c|c|c|c|c|c|c|c|c|c|c|c|}
\hline Registration \# & Trial \& Stage & $\begin{array}{l}\text { Neoadjuvant } \\
\text { Therapy }\end{array}$ & N (Plan) & $\begin{array}{c}\mathrm{N} \\
\text { (Reported) }\end{array}$ & $\begin{array}{c}\text { Delay of } \\
\text { Surgery }(\%)\end{array}$ & $\begin{array}{l}\text { Failure to } \\
\text { Surgery (\%) }\end{array}$ & $\begin{array}{c}\text { R0 } \\
\text { Resection } \\
(\%)\end{array}$ & $\begin{array}{c}\text { TRAE } \\
(\geq \text { G3) (\%) }\end{array}$ & MPR (\%) & pCR (\%) & Survival & Status & Ref. \\
\hline NCT02998528 & $\begin{array}{c}\text { Checkmate } 816 \\
\text { (p3) } \\
\text { IB to IIIA }\end{array}$ & $\begin{array}{l}\text { Nivolumab } \\
\text { + PT-DC vs. } \\
\text { PT-DC }\end{array}$ & 358 & 358 & 21 vs. 18 & 16 vs. 21 & 83 vs. 78 & $\begin{array}{c}\text { G3-4: } 19 \text { vs. } \\
21\end{array}$ & $\begin{array}{l}36.9 \text { vs. } 8.9 \\
(p<0.0001)\end{array}$ & $\begin{array}{c}24 \text { vs. } 2.2 \\
(p<0.0001)\end{array}$ & No data & $\begin{array}{l}\text { On } \\
\text { going }\end{array}$ & [35] \\
\hline NCT02716038 & $\begin{array}{l}\text { Columbia Univ. } \\
\text { (p2) } \\
\text { IB to IIIA }\end{array}$ & $\begin{array}{c}\text { atezolizumab } \\
+ \\
\text { CBDCA/Nab- } \\
\text { PTX }\end{array}$ & 30 & 30 & 0 & 3 & 87 & $\geq 50$ & 57 & 33 & $\begin{array}{c}\text { Median } \\
\text { OS/DFS: } \\
\text { NR/17.9 m }\end{array}$ & $\begin{array}{l}\text { On } \\
\text { going }\end{array}$ & [43] \\
\hline NCT02572843 & $\begin{array}{l}\text { SAKK16/14 (p2) } \\
\text { IIIA (pN2) }\end{array}$ & $\begin{array}{c}\text { durvalumab } \\
+ \\
\text { CDDP/DTX }\end{array}$ & 68 & 68 & No data & 19 & No data & Any: 88.1 & 60 & 18.2 & $\begin{array}{c}\text { Median } \\
\text { OS/EFS: } \\
\text { NR/NR } \\
\text { 1 y EFS: } \\
73.3 \%\end{array}$ & $\begin{array}{l}\text { On } \\
\text { going }\end{array}$ & [44] \\
\hline NCT03081689 & $\begin{array}{l}\text { NADIM (p2) } \\
\text { IIIA (pN2) }\end{array}$ & $\begin{array}{l}\text { nivolumab } \\
+ \text { CB- } \\
\text { DCA/PTX }\end{array}$ & 46 & 46 & 0 & 11 & 100 & 30 & 83 & 63 & $\begin{array}{c}\text { Median } \\
\text { PFS/OS: } \\
\text { NR/NR } \\
1 \text { y } \\
\text { PFS:95.7\% } \\
2 \text { y } \\
\text { PFS:77.1\% }\end{array}$ & $\begin{array}{l}\text { On } \\
\text { going }\end{array}$ & [36] \\
\hline NCT03694236 & $\begin{array}{l}\text { Yonsei Univ. (p2) } \\
\text { III (N2) }\end{array}$ & $\begin{array}{c}\text { durvalumab } \\
+ \text { CB- } \\
\text { DCA/PTX + } \\
\text { RT } 45 \text { Gy }\end{array}$ & 39 & 14 & No data & 8 & 100 & 7 & 72.7 & 36.4 & No data & $\begin{array}{l}\text { On } \\
\text { going }\end{array}$ & [41] \\
\hline
\end{tabular}

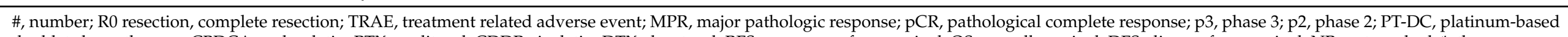

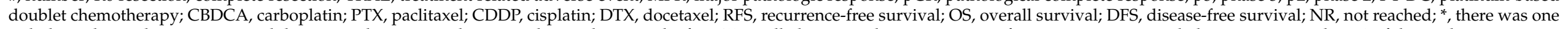
radiological complete response and three partial responses that were observed among the first 15 enrolled patients, but a minimum of six responses are needed to continue to phase 2 of the study. 
The results of the clinical trials for ICI mono- and dual therapies (Table 2) and ICI combination therapy (Table 3) suggest that the proportions of surgery delay, surgery failure, and complete resection were equivalent between ICI mono-/dual therapies and ICI combination therapy. In addition, although TRAEs of $\geq \mathrm{G} 3$ were more frequent in ICI combination therapy (19\% to $\geq 50 \%)$ than in ICI mono-/dual therapies (0-14\%), the MPR and pCR rates may increase in ICI combination therapy (37 to $83 \%$ and 9 to $63 \%$, respectively) compared to those in ICI monotherapy ( 0 to $45 \%$ and 7 to $15 \%$, respectively).

\section{Identification and Monitoring of MRD}

An attempt has been made to verify the progression and prognosis of cancer by quantifying tumour cells and tumour-derived DNA released into the blood (liquid biopsy) [46]. The quantification of the circulating tumour DNA (ctDNA) is expected to be an accurate determinant of the indications for perioperative treatment $[47,48]$. Since blood sample collection is relatively easy, repetitive assessment is acceptable for detecting disease progression and therapeutic effects. Of note, the Checkmate 816 trial showed that ctDNA clearance was more frequent in patients who received neoadjuvant nivolumab plus PT-DC (56\%) than in the neoadjuvant PT-DC alone group (34\%). Additionally, patients with ctDNA clearance showed higher pCR rates than patients without ctDNA clearance in both treatment groups: $46 \%$ vs. $0 \%$ in the nivolumab plus PT-DC group, respectively, and $13 \%$ vs. $3 \%$ in the PT-DC alone group, respectively [35].

The MeRmaiD-2 trial enrolled patients with stage II-III NSCLC who had completed curative-intent therapy (complete resection plus optional neoadjuvant and/or adjuvant therapy) during a 96-week surveillance period (Table 1 and Figure 2, NCT04642469) [49]. During this surveillance period, patients were monitored regularly for MRD emergence via ctDNA analysis using personalised MRD panels. Eligible patients for whom the presence of MRD was confirmed were randomised 1:1 to receive durvalumab or placebo.

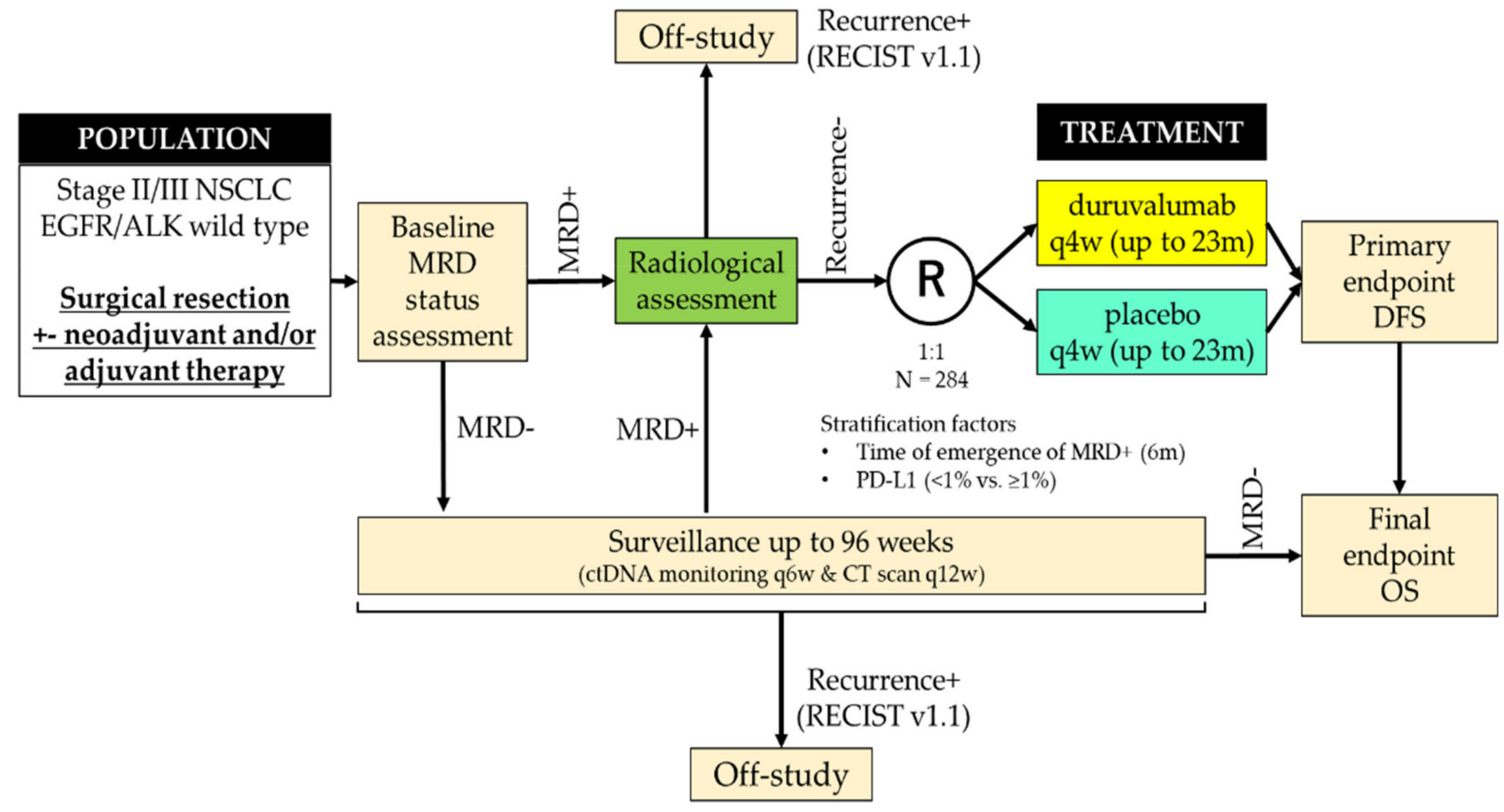

Figure 2. Study design of the MeRmaiD-2 trial (modified from the presentation of Spigel et al. [49]). The MeRmaiD-2 trial (NCT04642469) enrolled patients with stage II-III NSCLC after complete resection plus optional neoadjuvant and/or adjuvant therapy. Eligible patients in whom the presence of MRD was confirmed by regular monitoring for minimal residual disease (MRD) emergence via circulating tumor DNA (ctDNA) analysis during the surveillance period were randomised to receive durvalumab or placebo. 


\section{New ICI Agents}

Several new ICI agents are being examined in phase 2 trials as neoadjuvant ICI combination therapy (Table 4). Relatlimab is a monoclonal antibody for lymphocyte activation gene 3 (Lag-3), which negatively regulates $\mathrm{T}$ lymphocytes by binding to the extracellular domain of the ligand [50]. Oleclumab is an antibody against $5^{\prime}$-nucleotidase ecto, also known as CD73, which binds to CD73 and inhibits the production of immunosuppressive adenosine [51]. Monalizumab is an inhibitor of CD94/NK group 2 member A (NKG2A), an immune checkpoint molecule expressed on tumour-infiltrating cytotoxic T cells and natural killer cells [52]. Tiragolumab is a new immune checkpoint inhibitor blocking the interaction between T-cell immunoreceptors with immunoglobulin and immunoreceptor tyrosine-based inhibitory motif domains (TIGIT) and CD155 (RVR) [53]. Canakinumab is a monoclonal antibody that neutralises IL- $1 \beta$ activity by blocking its interaction with the IL-1 receptor expressed on activated cytotoxic $\mathrm{T}$ cells and Tregs [54]. Although canakinumab is a cancer immunotherapy drug (immunomodulator) but not an ICI, a phase 2 trial, Canopy-N, is under way to explore a neoadjuvant monotherapy of canakinumab and combination therapy with pembrolizumab in patients with stage IB to IIIA NSCLC (non-N2 or T4) [55].

Table 4. Clinical neoadjuvant trials using new ICI agents.

\begin{tabular}{|c|c|c|c|c|c|c|c|c|c|}
\hline Registration \# & Trial & Therapy & Phase & $\mathbf{N}$ & Stage & $\begin{array}{l}\text { New Agents } \\
\text { (Target) }\end{array}$ & Experimental Arm & Primary Endpoint & Country \\
\hline NCT04205552 & $\begin{array}{l}\text { NEOpredict- } \\
\text { Lung }\end{array}$ & ICI dual & 2 & 60 & $\begin{array}{c}\text { IB to } \\
\text { selected IIIA }\end{array}$ & $\begin{array}{c}\text { relatlimab } \\
(\text { Lag-3) }\end{array}$ & $\begin{array}{c}\text { Arm A: } \\
\text { nivolumab(twice) } \\
\text { Arm B: nivolumab + } \\
\text { relatlimab (twice) }\end{array}$ & Feasibility & $\begin{array}{c}\text { Belgium } \\
\text { Germany } \\
\text { Netherlands }\end{array}$ \\
\hline NCT03794544 & NeoCOAST & ICI dual & 2 & 80 & $\begin{array}{l}\text { I }(>2 \mathrm{~cm}) \text { to } \\
\text { IIIA }(\text { single } \\
\mathrm{N} 2 \leq 3 \mathrm{~cm})\end{array}$ & $\begin{array}{l}\text { oleclumab } \\
\text { (CD73) } \\
\text { monalizumab } \\
\text { (NKG2A) }\end{array}$ & $\begin{array}{c}\text { Arm A: } \\
\text { durvalumab } \\
\text { Arm B: durvalumab } \\
\text { + oleclumab } \\
\text { Arm C: } \\
\text { durvalumab + } \\
\text { monalizumab } \\
\text { Arm D: } \\
\text { durvalumab + } \\
\text { danvatirsen } \\
\text { PD-L1 high: }\end{array}$ & MPR & $\begin{array}{l}\text { Global } \\
\text { (Western } \\
\text { Countries) }\end{array}$ \\
\hline NCT04832854 & GO42501 & $\begin{array}{c}\text { ICI dual + } \\
\text { Chemo }\end{array}$ & 2 & 82 & $\begin{array}{c}\text { II to } \\
\text { IIIB(T3N2) }\end{array}$ & $\begin{array}{l}\text { tiragolumab } \\
\text { (TIGIT/RVR) }\end{array}$ & $\begin{array}{c}\text { Atezolizumab + } \\
\text { tiragolumab }(4 \\
\text { times) } \\
\text { PD-L1 All comers: } \\
\text { Atezolizumab + } \\
\text { tiragolumab + } \\
\text { PT-DC }(4 \text { times) }\end{array}$ & $\begin{array}{l}\text { 1. Surgical delays, } \\
\text { 2. Complications, } \\
\text { 3. Cancellations of } \\
\text { surgery, } \\
\text { 4. AE, } \\
\text { 5. MPR }\end{array}$ & $\begin{array}{c}\text { US } \\
\text { Spain } \\
\text { Switzerland }\end{array}$ \\
\hline NCT03968419 & CANOPY-N & $\mathrm{ICI}+\mathrm{IM}$ & 2 & 110 & $\begin{array}{c}\text { IB to IIIA } \\
\text { (non-N2 nor } \\
\text { T4) }\end{array}$ & $\begin{array}{c}\text { canakinumab } \\
(\text { IL-1 } \beta)\end{array}$ & $\begin{array}{c}\text { Arm A: } \\
\text { canakinumab } \\
\text { Arm B: } \\
\text { canakinumab + } \\
\text { pembrolizumab } \\
\text { Arm C: } \\
\text { pembrolizumab }\end{array}$ & MPR & Global \\
\hline
\end{tabular}

\#, number; ICI, immune checkpoint inhibitor; IM, immunomodulator; MPR, major pathologic response; AE, adverse event; danvatisen, a signal transducer and activator of transcription 3 (STAT3) transcription factor inhibitor.

\section{Conclusions and Future Perspectives}

Several phase 3 trials using ICIs in the preoperative, postoperative, and both settings are being conducted. The primary results are promising regarding the efficacy of the introduction of ICI in the perioperative phase. The final results of these trials may have a significant impact on the treatment strategies for patients with resectable NSCLC. In addition, the usefulness of ctDNA-based monitoring for MRD should also be substantiated by phase 3 trials to identify patients who genuinely need perioperative therapy with ICI. This approach may provide better clinical outcomes by intensifying the treatment for patients with a high probability of relapse and who are avoiding the unnecessary administration of additional adjuvant chemotherapy (Figure 3). 
At diagnosis

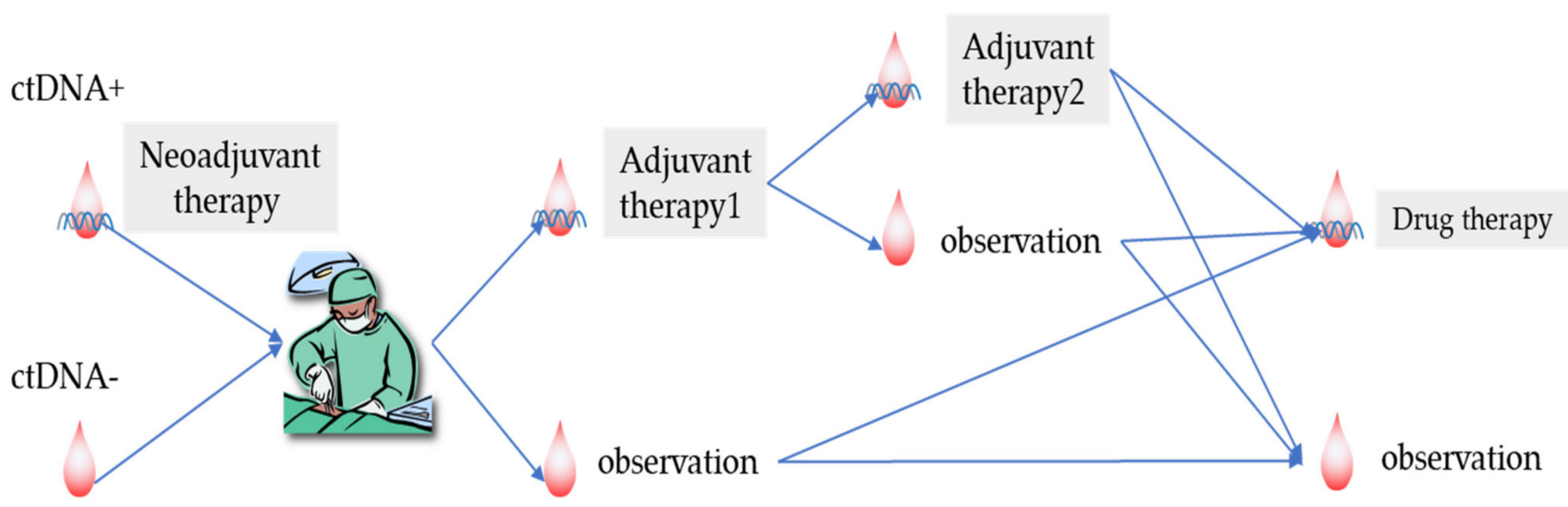

After surgery

During follow up

Figure 3. ctDNA-guided perioperative management in the future. This figure demonstrates a future perioperative treatment strategy for patients with resectable NSCLC according to the minimal residual disease assessment. The treatment strategy for neoadjuvant and adjuvant therapies will be determined based on the status of circulating tumour DNA (ctDNA) at diagnosis, after surgery, and during the surveillance period.

However, there are several concerns associated with ICI-containing therapies, including the optimisation of ICI administration methods (dosage, dose interval, dose frequency), the optimisation of combination therapies (appropriate regimen and administration methods), and the improved management of ICI-related side effects. These issues should be addressed in basic research and clinical trials. Aggregation of these results would significantly enhance the clinical outcomes of patients with resectable NSCLC.

In conclusion, the initial results of clinical trials on perioperative therapies using ICIs in patients with lung cancer show improved clinical outcomes compared to the current standard of care. Several early phase trials are also investigating the efficacy of novel ICIs. The development of appropriate patient selection methods for perioperative ICIs, such as MRD detection via ctDNA assay, is warranted to maximise the therapeutic effect of perioperative ICIs and to avoid unnecessary administration.

Supplementary Materials: The following are available online at https: / www.mdpi.com/article / 10.3390 / cancers13164035/s1, Table S1: Clinical trials of neoadjuvant therapy using combination regimens of ICIs (phase $2 / 3$ ).

Author Contributions: Conceptualization, J.S. and T.M.; methodology, J.S. and T.M.; investigation, J.S.; writing —original draft preparation, J.S.; writing—review and editing, T.M.; visualization, A.H. and T.F.; supervision, T.M.; project administration, J.S.; funding acquisition, J.S. All authors have read and agreed to the published version of the manuscript.

Funding: This research received no external funding.

Conflicts of Interest: The authors declare no conflict of interest related to this work. However, all authors have conflicts of interest outside of their direct responsibility within this work as follows: J.S. has received grants-in-aid for scientific research from the Japan Society for the Promotion of Science (grants 19K09285, 19H03746, 19K09286, 18K08783, and 18K19581) and the honorarias from Intutive, Ethicon, and Covidien. A.H. has received grants-in-aid for scientific research from the Japan Society for Promotion of Science (grant 20K17763) and lecture fees from AstraZeneca and Chugai. T.F. has received grants-in-aid for scientific research from the Japan Society for the Promotion of Science (grant 19K16813), research funding from Apollomics, and honoraria from Novartis. T.M. has received research funding from Boehringer-Ingelheim, MSD, Taiho, Chugai, Eli-Lilly, and Ono, the honorarias from AstraZeneca, Boehringer Ingelheim, Novartis, MSD, BMS, Ono, Chugai, Merck Biopharma, Takeda, Pfizer, and Eli-Lilly. T.M. participates on the advisory boards of AstraZeneca, Amgen, Janssen Pharma, MSD, and Puma Biotech and has a leadership position in the International Association for the Study of Lung Cancer. 


\section{References}

1. Siegel, R.L.; Miller, K.D.; Jemal, A. Cancer statistics, 2019. CA A Cancer J. Clin. 2019, 69, 7-34. [CrossRef] [PubMed]

2. Goldstraw, P.; Chansky, K.; Crowley, J.; Rami-Porta, R.; Asamura, H.; Eberhardt, W.E.; Nicholson, A.G.; Groome, P.; Mitchell, A.; Bolejack, V.; et al. The IASLC Lung Cancer Staging Project: Proposals for Revision of the TNM Stage Groupings in the Forthcoming (Eighth) Edition of the TNM Classification for Lung Cancer. J. Thorac. Oncol. 2016, 11, 39-51. [CrossRef] [PubMed]

3. Pignon, J.P.; Tribodet, H.; Scagliotti, G.V.; Douillard, J.Y.; Shepherd, F.A.; Stephens, R.J.; Dunant, A.; Torri, V.; Rosell, R.; Seymour, L.; et al. Lung Adjuvant Cisplatin Evaluation: A Pooled Analysis by the LACE Collaborative Group. J. Clin. Oncol. 2008, 26, 3552-3559. [CrossRef]

4. Reck, M.; Rodríguez-Abreu, D.; Robinson, A.G.; Hui, R.; Csőszi, T.; Fülöp, A.; Gottfried, M.; Peled, N.; Tafreshi, A.; Cuffe, S.; et al. Pembrolizumab versus Chemotherapy for PD-L1-Positive Non-Small-Cell Lung Cancer. N. Engl. J. Med. 2016, 375, $1823-1833$. [CrossRef] [PubMed]

5. Gandhi, L.; Rodríguez-Abreu, D.; Gadgeel, S.; Esteban, E.; Felip, E.; De Angelis, F.; Domine, M.; Clingan, P.; Hochmair, M.J.; Powell, S.F.; et al. Pembrolizumab plus Chemotherapy in Metastatic Non-Small-Cell Lung Cancer. N. Engl. J. Med. 2018, 378, 2078-2092. [CrossRef]

6. Hellmann, M.D.; Paz-Ares, L.; Bernabe Caro, R.; Zurawski, B.; Kim, S.W.; Carcereny Costa, E.; Park, K.; Alexandru, A.; Lupinacci, L.; de la Mora Jimenez, E.; et al. Nivolumab plus Ipilimumab in Advanced Non-Small-Cell Lung Cancer. N. Engl. J. Med. 2019, 381, 2020-2031. [CrossRef]

7. Antonia, S.J.; Villegas, A.; Daniel, D.; Vicente, D.; Murakami, S.; Hui, R.; Kurata, T.; Chiappori, A.; Lee, K.H.; de Wit, M.; et al. Overall Survival with Durvalumab after Chemoradiotherapy in Stage III NSCLC. N. Engl. J. Med. 2018, 379, 2342-2350. [CrossRef]

8. Antonia, S.J.; Villegas, A.; Daniel, D.; Vicente, D.; Murakami, S.; Hui, R.; Yokoi, T.; Chiappori, A.; Lee, K.H.; de Wit, M.; et al. Durvalumab after Chemoradiotherapy in Stage III Non-Small-Cell Lung Cancer. N. Engl. J. Med. 2017, 377, 1919-1929. [CrossRef]

9. NSCLC Meta-Analysis Collaborative Group. Preoperative chemotherapy for non-small-cell lung cancer: A systematic review and meta-analysis of individual participant data. Lancet 2014, 383, 1561-1571. [CrossRef]

10. Albain, K.S.; Swann, R.S.; Rusch, V.W.; Turrisi, A.T., 3rd; Shepherd, F.A.; Smith, C.; Chen, Y.; Livingston, R.B.; Feins, R.H.; Gandara, D.R.; et al. Radiotherapy plus chemotherapy with or without surgical resection for stage III non-small-cell lung cancer: A phase III randomised controlled trial. Lancet 2009, 374, 379-386. [CrossRef]

11. Mok, T.S.K.; Wu, Y.L.; Kudaba, I.; Kowalski, D.M.; Cho, B.C.; Turna, H.Z.; Castro, G., Jr.; Srimuninnimit, V.; Laktionov, K.K.; Bondarenko, I.; et al. Pembrolizumab versus chemotherapy for previously untreated, PD-L1-expressing, locally advanced or metastatic non-small-cell lung cancer (KEYNOTE-042): A randomised, open-label, controlled, phase 3 trial. Lancet 2019, 393, 1819-1830. [CrossRef]

12. Herbst, R.S.; Giaccone, G.; de Marinis, F.; Reinmuth, N.; Vergnenegre, A.; Barrios, C.H.; Morise, M.; Felip, E.; Andric, Z.; Geater, S.; et al. Atezolizumab for First-Line Treatment of PD-L1-Selected Patients with NSCLC. N. Engl. J. Med. 2020, 383, 1328-1339. [CrossRef]

13. Paz-Ares, L.; Luft, A.; Vicente, D.; Tafreshi, A.; Gümüş, M.; Mazières, J.; Hermes, B.; Çay Şenler, F.; Csőszi, T.; Fülöp, A.; et al. Pembrolizumab plus chemotherapy for squamous non-small-cell lung cancer. N. Engl. J. Med. 2018, 379, 2040-2051. [CrossRef] [PubMed]

14. Wakelee, H.A.; Altorki, N.K.; Zhou, C.; Csőszi, T.; Vynnychenko, I.O.; Goloborodko, O.; Luft, A.; Akopov, A.; Martinez-Marti, A.; Kenmotsu, H.; et al. IMpower010: Primary results of a phase III global study of atezolizumab versus best supportive care after adjuvant chemotherapy in resected stage IB-IIIA non-small cell lung cancer (NSCLC). J. Clin. Oncol. 2021, 39, 8500. [CrossRef]

15. Blumenthal, G.M.; Bunn, P.A.; Chaft, J.E.; McCoach, C.E.; Perez, E.A.; Scagliotti, G.V.; Carbone, D.P.; Aerts, H.J.W.L.; Aisner, D.L.; Bergh, J.; et al. Current Status and Future Perspectives on Neoadjuvant Therapy in Lung Cancer. J. Thorac. Oncol. 2018, 13, 1818-1831. [CrossRef] [PubMed]

16. Kris, M.G.; Faivre-Finn, C.; Kordbacheh, T.; Chaft, J.; Luo, J.; Tsao, A.; Swisher, S. Making Checkpoint Inhibitors Part of Treatment of Patients with Locally Advanced Lung Cancers: The Time Is Now. Am. Soc. Clin. Oncol. Educ. Book Am. Soc. Clin. Oncol. Annu. Meet. 2020, 40, e159-e170. [CrossRef]

17. Topalian, S.L.; Taube, J.M.; Pardoll, D.M. Neoadjuvant checkpoint blockade for cancer immunotherapy. Science 2020, 367. [CrossRef]

18. Liu, J.; Blake, S.J.; Yong, M.C.; Harjunpaa, H.; Ngiow, S.F.; Takeda, K.; Young, A.; O'Donnell, J.S.; Allen, S.; Smyth, M.J.; et al. Improved Efficacy of Neoadjuvant Compared to Adjuvant Immunotherapy to Eradicate Metastatic Disease. Cancer Discov. 2016, 6, 1382-1399. [CrossRef]

19. Bossuyt, V.; Provenzano, E.; Symmans, W.F.; Boughey, J.C.; Coles, C.; Curigliano, G.; Dixon, J.M.; Esserman, L.J.; Fastner, G.; Kuehn, T.; et al. Recommendations for standardized pathological characterization of residual disease for neoadjuvant clinical trials of breast cancer by the BIG-NABCG collaboration. Ann. Oncol. 2015, 26, 1280-1291. [CrossRef]

20. Marchiò, C.; Maletta, F.; Annaratone, L.; Sapino, A. The Perfect Pathology Report After Neoadjuvant Therapy. JNCI Monogr. 2015, 2015, 47-50. [CrossRef]

21. Bossuyt, V.; Symmans, W.F. Standardizing of Pathology in Patients Receiving Neoadjuvant Chemotherapy. Ann. Surg. Oncol. 2016, 23, 3153-3161. [CrossRef]

22. Bossuyt, V. Processing and Reporting of Breast Specimens in the Neoadjuvant Setting. Surg. Pathol. Clin. 2018, 11, 213-230. [CrossRef] [PubMed] 
23. Pataer, A.; Kalhor, N.; Correa, A.M.; Raso, M.G.; Erasmus, J.J.; Kim, E.S.; Behrens, C.; Lee, J.J.; Roth, J.A.; Stewart, D.J.; et al. Histopathologic response criteria predict survival of patients with resected lung cancer after neoadjuvant chemotherapy. J. Thorac. Oncol. 2012, 7, 825-832. [CrossRef] [PubMed]

24. William, W.N., Jr.; Pataer, A.; Kalhor, N.; Correa, A.M.; Rice, D.C.; Wistuba, I.I.; Heymach, J.; Lee, J.J.; Kim, E.S.; Munden, R.; et al. Computed tomography RECIST assessment of histopathologic response and prediction of survival in patients with resectable non-small-cell lung cancer after neoadjuvant chemotherapy. J. Thorac. Oncol. 2013, 8, 222-228. [CrossRef]

25. Junker, K.; Langner, K.; Klinke, F.; Bosse, U.; Thomas, M. Grading of Tumor Regression in Non-small Cell Lung Cancer: Morphology and Prognosis. Chest 2001, 120, 1584-1591. [CrossRef] [PubMed]

26. Hellmann, M.D.; Chaft, J.E.; William, W.N., Jr.; Rusch, V.; Pisters, K.M.; Kalhor, N.; Pataer, A.; Travis, W.D.; Swisher, S.G.; Kris, M.G. Pathological response after neoadjuvant chemotherapy in resectable non-small-cell lung cancers: Proposal for the use of major pathological response as a surrogate endpoint. Lancet Oncol. 2014, 15, e42-e50. [CrossRef]

27. Qu, Y.; Emoto, K.; Eguchi, T.; Aly, R.G.; Zheng, H.; Chaft, J.E.; Tan, K.S.; Jones, D.R.; Kris, M.G.; Adusumilli, P.S.; et al. Pathologic Assessment after Neoadjuvant Chemotherapy for NSCLC: Importance and Implications of Distinguishing Adenocarcinoma from Squamous Cell Carcinoma. J. Thorac. Oncol. 2019, 14, 482-493. [CrossRef]

28. Travis, W.D.; Dacic, S.; Wistuba, I.; Sholl, L.; Adusumilli, P.; Bubendorf, L.; Bunn, P.; Cascone, T.; Chaft, J.; Chen, G.; et al. IASLC Multidisciplinary Recommendations for Pathologic Assessment of Lung Cancer Resection Specimens After Neoadjuvant Therapy. J. Thorac. Oncol. 2020, 15, 709-740. [CrossRef]

29. Besse, B.; Adam, J.; Cozic, N.; Chaput-Gras, N.; Planchard, D.; Mezquita, L.; Masip, J.R.; Lavaud, P.; Naltet, C.; Gazzah, A.; et al. 1215O-SC Neoadjuvant atezolizumab (A) for resectable non-small cell lung cancer (NSCLC): Results from the phase II PRINCEPS trial. Ann. Oncol. 2020, 31, S794-S795. [CrossRef]

30. Cascone, T.; William, W.N., Jr.; Weissferdt, A.; Leung, C.H.; Lin, H.Y.; Pataer, A.; Godoy, M.C.B.; Carter, B.W.; Federico, L.; Reuben, A.; et al. Neoadjuvant nivolumab or nivolumab plus ipilimumab in operable non-small cell lung cancer: The phase 2 randomized NEOSTAR trial. Nat. Med. 2021, 27, 504-514. [CrossRef]

31. Forde, P.M.; Chaft, J.E.; Smith, K.N.; Anagnostou, V.; Cottrell, T.R.; Hellmann, M.D.; Zahurak, M.; Yang, S.C.; Jones, D.R.; Broderick, S.; et al. Neoadjuvant PD-1 Blockade in Resectable Lung Cancer. N. Engl. J. Med. 2018, 378, 1976-1986. [CrossRef] [PubMed]

32. Lee, J.; Chaft, J.; Nicholas, A.; Patterson, A.; Waqar, S.; Toloza, E.; Haura, E.; Raz, D.; Reckamp, K.; Merritt, R.; et al. PS01.05 Surgical and Clinical Outcomes with Neoadjuvant Atezolizumab in Resectable Stage IB-IIIB NSCLC: LCMC3 Trial Primary Analysis. J. Thorac. Oncol. 2021, 16, S59-S61. [CrossRef]

33. Wislez, M.; Mazieres, J.; Lavole, A.; Zalcman, G.; Carre, O.; Egenod, T.; Caliandro, R.; Gervais, R.; Jeannin, G.; Molinier, O.; et al. $1214 \mathrm{O}$ Neoadjuvant durvalumab in resectable non-small cell lung cancer (NSCLC): Preliminary results from a multicenter study (IFCT-1601 IONESCO). Ann. Oncol. 2020, 31, S794. [CrossRef]

34. Sharma, P.; Allison, J.P. The future of immune checkpoint therapy. Science 2015, 348, 56-61. [CrossRef] [PubMed]

35. Forde, P.M.; Spicer, J.; Lu, S.; Provencio, M.; Mitsudomi, T.; Awad, M.M.; Felip, E.; Broderick, S.; Brahmer, J.; Swanson, S.J.; et al. Nivolumab + platinum-doublet chemotherapy vs chemotherapy as neoadjuvant treatment for resectable (IB-IIIA) non-small cell lung cancer in the phase 3 CheckMate 816 trial. In Proceedings of the American Association for Cancer Research Annual Meeting, Philadelphia, PA, USA, 10-15 April 2021. Virtual.

36. Provencio, M.; Nadal, E.; Insa, A.; García-Campelo, M.R.; Casal-Rubio, J.; Dómine, M.; Majem, M.; Rodríguez-Abreu, D.; Martínez-Martí, A.; De Castro Carpeño, J.; et al. Neoadjuvant chemotherapy and nivolumab in resectable non-small-cell lung cancer (NADIM): An open-label, multicentre, single-arm, phase 2 trial. Lancet Oncol. 2020, 21, 1413-1422. [CrossRef]

37. Mole, R.H. Whole body irradiation; radiobiology or medicine? Br. J. Radiol. 1953, 26, 234-241. [CrossRef] [PubMed]

38. Demaria, S.; Ng, B.; Devitt, M.L.; Babb, J.S.; Kawashima, N.; Liebes, L.; Formenti, S.C. Ionizing radiation inhibition of distant untreated tumors (abscopal effect) is immune mediated. Int. J. Radiat. Oncol. Biol. Phys. 2004, 58, 862-870. [CrossRef] [PubMed]

39. Ngwa, W.; Irabor, O.C.; Schoenfeld, J.D.; Hesser, J.; Demaria, S.; Formenti, S.C. Using immunotherapy to boost the abscopal effect. Nat. Rev. Cancer 2018, 18, 313-322. [CrossRef]

40. Gray, J.E.; Villegas, A.; Daniel, D.; Vicente, D.; Murakami, S.; Hui, R.; Kurata, T.; Chiappori, A.; Lee, K.H.; Cho, B.C.; et al. Three-Year Overall Survival with Durvalumab after Chemoradiotherapy in Stage III NSCLC-Update from PACIFIC. J. Thorac. Oncol. 2020, 15, 288-293. [CrossRef]

41. Hong, M.H.; Ahn, B.; Kim, H.R.; Lim, S.M.; Lee, S.; Park, S.Y.; Lee, C.Y.; Lee, J.G.; Kim, D.J.; Lee, S.H.; et al. FP03.02 Interim Analysis of Neoadjuvant Chemoradiotherapy and Durvalumab for Potentially Resectable Stage III Non-Small Cell Lung Cancer (NSCLC). J. Thorac. Oncol. 2021, 16, S194-S195. [CrossRef]

42. Hamada, A.; Soh, J.; Hata, A.; Nakamatsu, K.; Shimokawa, M.; Yatabe, Y.; Oizumi, H.; Tsuboi, M.; Horinouchi, H.; Yoshino, I.; et al. Phase II Study of Neoadjuvant Concurrent Chemo-immuno-radiation Therapy Followed by Surgery and Adjuvant Immunotherapy for Resectable Stage IIIA-B (Discrete N2) Non-Small Cell Lung Cancer: SQUAT trial (WJOG 12119L). Clin. Lung Cancer 2021, in press. [CrossRef]

43. Shu, C.A.; Gainor, J.F.; Awad, M.M.; Chiuzan, C.; Grigg, C.M.; Pabani, A.; Garofano, R.F.; Stoopler, M.B.; Cheng, S.K.; White, A.; et al. Neoadjuvant atezolizumab and chemotherapy in patients with resectable non-small-cell lung cancer: An open-label, multicentre, single-arm, phase 2 trial. Lancet Oncol. 2020, 21, 786-795. [CrossRef] 
44. Rothschild, S.; Zippelius, A.; Eboulet, E.I.; Savic, S.; Betticher, D.C.; Bettini, A.; Frueh, M.; Joerger, M.; Britschgi, C.; Peters, S.; et al. SAKK 16/14: Anti-PD-L1 antibody durvalumab in addition to neoadjuvant chemotherapy in patients with stage IIIA(N2) non-small cell lung cancer (NSCLC)_A multicenter single-arm phase II trial. J. Clin. Oncol. 2020, 38, 9016. [CrossRef]

45. Tfayli, A.; Al Assaad, M.; Fakhri, G.; Akel, R.; Atwi, H.; Ghanem, H.; El Karak, F.; Farhat, F.; Al Rabi, K.; Sfeir, P.; et al. Neoadjuvant chemotherapy and Avelumab in early stage resectable nonsmall cell lung cancer. Cancer Med. 2020, 9, 8406-8411. [CrossRef] [PubMed]

46. Alix-Panabieres, C.; Pantel, K. Clinical Applications of Circulating Tumor Cells and Circulating Tumor DNA as Liquid Biopsy. Cancer Discov. 2016, 6, 479-491. [CrossRef]

47. Abbosh, C.; Birkbak, N.J.; Wilson, G.A.; Jamal-Hanjani, M.; Constantin, T.; Salari, R.; Le Quesne, J.; Moore, D.A.; Veeriah, S.; Rosenthal, R.; et al. Phylogenetic ctDNA analysis depicts early-stage lung cancer evolution. Nature 2017, 545, 446-451. [CrossRef]

48. Ohara, S.; Suda, K.; Sakai, K.; Nishino, M.; Chiba, M.; Shimoji, M.; Takemoto, T.; Fujino, T.; Koga, T.; Hamada, A.; et al. Prognostic implications of preoperative versus postoperative circulating tumor DNA in surgically resected lung cancer patients: A pilot study. Transl. Lung Cancer Res. 2020, 9, 1915-1923. [CrossRef]

49. Spigel, D.R.; Peters, S.; Ahn, M.J.; Tsuboi, M.; Chaft, J.; Harpole, D.; Barlesi, F.; Abbosh, C.; Mann, H.; May, R.; et al. 93TiP MERMAID-2: Phase III study of durvalumab in patients with resected, stage II-III NSCLC who become MRD+ after curative-intent therapy. J. Thorac. Oncol. 2021, 16, S745-S746. [CrossRef]

50. Yu, X.; Huang, X.; Chen, X.; Liu, J.; Wu, C.; Pu, Q.; Wang, Y.; Kang, X.; Zhou, L. Characterization of a novel anti-human lymphocyte activation gene 3 (LAG-3) antibody for cancer immunotherapy. mAbs 2019, 11, 1139-1148. [CrossRef]

51. Hay, C.M.; Sult, E.; Huang, Q.; Mulgrew, K.; Fuhrmann, S.R.; McGlinchey, K.A.; Hammond, S.A.; Rothstein, R.; Rios-Doria, J.; Poon, E.; et al. Targeting CD73 in the tumor microenvironment with MEDI9447. Oncoimmunology 2016, 5, e1208875. [CrossRef]

52. Van Hall, T.; André, P.; Horowitz, A.; Ruan, D.F.; Borst, L.; Zerbib, R.; Narni-Mancinelli, E.; van der Burg, S.H.; Vivier, E. Monalizumab: Inhibiting the novel immune checkpoint NKG2A. J. Immunother. Cancer 2019, 7, 263. [CrossRef] [PubMed]

53. Yeo, J.; Ko, M.; Lee, D.-H.; Park, Y.; Jin, H.-S. TIGIT/CD226 Axis Regulates Anti-Tumor Immunity. Pharmaceuticals 2021, 14, 200. [CrossRef] [PubMed]

54. Mantovani, A.; Dinarello, C.A.; Molgora, M.; Garlanda, C. Interleukin-1 and Related Cytokines in the Regulation of Inflammation and Immunity. Immunity 2019, 50, 778-795. [CrossRef] [PubMed]

55. Garrido, P.; Pujol, J.L.; Kim, E.S.; Lee, J.M.; Tsuboi, M.; Gómez-Rueda, A.; Benito, A.; Moreno, N.; Gorospe, L.; Dong, T.; et al. Canakinumab with and without pembrolizumab in patients with resectable non-small-cell lung cancer: CANOPY-N study design. Future Oncol. 2021, 17, 1459-1472. [CrossRef] 